\title{
KEJADIAN PREMENSTRUAL SYNDROME (PMS) BERDASARKAN KARAKTERISTIK SISWI KELAS XII DI PONDOK PESANTREN SUKOHARJO
}

\author{
Wijayanti $^{1)}$, Tri Sunarsih ${ }^{2)}$, Farida Kartini ${ }^{3)}$, Dheny Rohmatika ${ }^{4)}$ \\ 1,4 Universitas Kusuma Husada Surakarta \\ ${ }^{2}$ Universitas Jenderal Ahmad Yani Yogyakarta \\ ${ }^{3}$ Universitas Aisyiyah Yogyakarta \\ email: haryantowijayanti@gmail.com
}

\begin{abstract}
ABSTRAK
Premenstrual Syndrome (PMS) adalah gejala fisik, psikologis dan emosi yang terjadi sebelum menstruasi. Dampak yang timbul adalah dapat menganggu aktivitas seorang wanita. Penelitian ini bertujuan untuk mengetahui kejadian premenstrual syndrome (PMS) berdasarkan karakteristik siswi kelas XII di Pondok Pesantren Sukoharjo. Metode penelitian diskriptif dengan analisa kuantitatif, rancangan cross sectional. Subyek penelitian adalah siswi kelas XII dengan PMS di Pondok Pesantren Sukoharjo yang diambil secara total sampling. Hasil dari penelitian yang telah dilakukan adalah bahwa di Pondok Pesantren Sukoharjo dengan responden sebanyak 34 siswi kelas XII dengan PMS, didapatkan hasil yaitu mayoritas umur responden yaitu 17 tahun $(70,6 \%)$, usia menarche 13-15 tahun (52,9\%), lama menstruasi $\geq 7$ hari (76,5\%), siklus menstruasi 28 hari $(76,5 \%)$, ganti pembalut $\geq 3$ kali perhari $(85,3 \%)$ dan IMT dengan berat badan ideal $(82,4 \%)$.
\end{abstract}

Kata kunci: ganti pembalut; imt; lama menstruasi; premenstrual syndrome; siklus menstruasi; umur; usia menarche

\begin{abstract}
Premenstrual Syndrome (PMS) is a physical, psychological and emotional symptom that occurs before menstruation. The impact that arises is that it can disrupt a woman's activities. This study aims to determine the incidence of premenstrual syndrome (PMS) based on the characteristics of class XII students at the Boarding School Sukoharjo. Descriptive research method with quantitative analysis, cross sectional design. The subjects of the study were students of class XII with PMS at Boarding School Sukoharjo taken in total sampling. The results of the research that has been done is that at the Boarding School Sukoharjo with 34 respondents in class XII with PMS, the results obtained are the majority of respondents' age is 17 years (70.6\%), menarche age 13-15 years (52, 9\%), menstruation duration $\geq 7$ days (76.5\%), menstrual cycle 28 days (76.5\%), dressing pads $\geq 3$ times per day (85.3\%) and BMI with ideal body weight (82.4\%).
\end{abstract}

Keywords: age; age of menarche; BMI; dressing pads; length of menstruation; menstrual cycle; premenstrual syndrome 


\section{PENDAHULUAN}

Pubertas merupakan salah satu fase dalam pertumbuhan dan perkembangan manusia. Pada wanita, pubertas diikuti aspek perkembangan reproduksi yang ditandai dengan mulainya mesntruasi (menarche). Banyak wanita mengalami ketidaknyamanan fisik selama beberapa hari sebelum periode menstruasi datang. Gejala-gejala dari ganggua menstruasi mulai dari rasa tidak nyaman pada daerah perut sampai masalah ketidakstabilan emosi, kondisi ini yang dikenal dengan premenstrual syndrome (sindroma premenstruasi).

Premenstrual Syndrome (PMS) adalah kumpulan gejala fisik, psikologis, dan emosi yang terkait dengan siklus menstruasi wanita. Gejala ini terjadi sebelum haid dan menghilang dengan keluarnya darah menstruasi serta dialami oleh banyak perempuan sebelum awitan setiap siklus menstruasi (Smeltzer, 2013). Keparahan dan frekuensi gejala yang dialami bisa berbeda di antara masing-masing siklus menstruasi. Gejala yang paling parah dan paling sering pada PMS adalah iritabilitas emosional dan tingkah laku, depresi, gelisah, kelelahan, konsentrasi berkurang, pembengkakan dan rasa tidak nyaman pada payudara dan nyeri di daerah perut (Halbreich et al, 2009).

Berdasarkan laporan WHO (World Health Organization), negara-negara Asia memiliki angka prevalensi PMS lebih tinggi di dibandingkan dengan negara-negara Barat (Mohamadirizi \& Kordi, 2013). Angka prevalensi PMS di Indonesia mencapai $85 \%$ dari populasi wanita usia reproduksi (Suparman, 2013), sedangkan angka prevalensi PMS pada remaja putri di Sri Lanka sekitar 65,7\% (ACOG, 2015), Iran sekitar $98,2 \%$ perempuan yang berumur 18 27 tahun mengalami paling sedikit 1 gejala PMS derajat ringan atau sedang (Mahin Delara, 2013). Angka prevalensi PMS di negara Brazil 39\% dan Amerika 34\% (Basir et al, 2012). Prevalensi PMS di Asia Pasifik, negara Jepang 34\%, Hongkong 17\%, Pakistan 13\%, Australia 44\% perempuan dewasa (Sylvia, 2010). Angka prevalensi PMS tidak terkait dengan usia, prestasi pendidikan dan status pekerjaan (Potter, 2009).

Prevalensi PMS di beberapa lokasi di Indonesia menunjukkan hasil yang berbeda. Prevalensi PMS pada siswi SMK di Jakarta Selatan menunjukkan 45\% siswi mengalami PMS (Devi, 2009). Prevalensi PMS pada mahasiswi Akademi Kebidanan di Kudus sebanyak 45,8\% (Puspitorini et al, 2007). Prevalensi PMS pada siswi SMA di Padang menunjukkan 51,8\% (Siantina, 2010), sedangkan prevalensi PMS pada siswi SMA di Purworejo 24,6\% (Nurmiaty, 2011). Prevalensi PMS pada siswa SMA di Surabaya sebanyak $39,2 \%$ mengalami gejala berat dan $60,8 \%$ mengalami gejala ringan (Cristianty, 2009). Berdasarkan penelitian (Essel, 2009), dalam suatu penelitian terhadap 384 wanita yang berusia 15 tahun melaporkan bahwa 14\% dari wanita tersebut mengalami PMS.

Dampak PMS bagi wanita adalah meningkatnya jumlah absensi kerja, biaya pengobatan yang besar dan kualitas kesehatan yang rendah karena menganggu aktivitas perempuan (Oberman, 2018). Masalah PMS yang dihadapi remaja putri, dapat mempengaruhi kesehatan fisik dan fungsi sosial, sehingga menyebabkan ketidakmampuan untuk aktivitas sehingga prestasi belajar yang kurang (Saryono dan Waluyo, 2009).

Berdasarkan studi pendahuluan yang dilakukan peneliti di Pondok Pesantren Sukoharjo pada tanggal 19 Mei 2019 diperoleh bahwa 415 siswi yang terdiri dari SMA 218 siswi dan SMP 197 siswi. Dari total jumlah tersebut, didapatkan 25-30\% siswi mengalami PMS. Gambaran PMS yang dialami oleh siswi yaitu pusing, 
mual, muntah, badan terasa berat dan kaku, payudara tegang, mudah marah/emosi dan cemas.

Berdasarkan uraian diatas rumusan masalahnya adalah : "Bagaimanakah kejadian premenstrual syndrome (PMS) berdasarkan karakteristik siswi kelas XII di Pondok Pesantren Sukoharjo?"

Tujuan penelitian ini adalah mengetahui kejadian premenstrual syndrome (PMS) berdasarkan karakteristik siswi kelas XII di Pondok Pesantren Sukoharjo.

\section{METODE PENELITIAN}

Jenis penelitian adalah penelitian diskriptif dengan analisa kuantitatif, Dengan rancangan cross sectional, jumlah populasi dalam penelitian ini adalah 51 siswi kelas XII di Pondok Pesantren Sukoharjo. Jumlah sampel dalam penelitian ini sebanyak 34 siswi. Teknik yang digunakan dalam penelitian ini adalah total sampling dengan kriteria inklusi dan eksklusi. Kriteria inklusi yaitu siswi kelas XII yang sudah menstruasi dan mengalami gejala PMS minimal 2 siklus menstruasi dan kriteria eksklusi yaitu siswi yang tidak hadir di kelas. Penelitian dilakukan pada bulan Januari 2020. Variabel dalam penelitian ini adalah variabel tunggal yaitu kejadian premenstrual syndrome. Teknik pengumpulan data yaitu dengan data sekunder dan data primer. Instrumen penelitian dengan menggunakan lembar kuesioner untuk kejadian PMS pada siswi. Penelitian ini telah melalui uji etik dengan ethical clearance nomor: 1.200/XI/HREC/2019.

\section{HASIL DAN PEMBAHASAN}

a. Gambaran Lokasi Penelitian

Pondok Pesantren Sukoharjo adalah salah satu pondok pesantren dengan sistem pendidikan modern yang didirikan oleh Pimpinan Cabang Muhammadiyah Blimbing Daerah Sukoharjo pada tahun 1994 terletak di Jalan KH. Ahmad Dahlan No.154 Desa Blimbing Wonorejo,
Kecamatan Polokarto, Kabupaten Sukoharjo dengan luas tanah 10.308 $\mathrm{m}^{2}$. Jenjang pendidikan di Pondok Pesantren Sukoharjo terdiri dari Madrasah Tsanawiyah (Mts), Madrasah Takhasusiyah (TKS) dan Sekolah Menengah Atas (SMA). Fasilitas pendukung yang dimiliki Pondok Pesantren Sukoharjo adalah komplek pondok putra, komplek pondok putri dan Pos Kesehatan Pesantren (Poskentren). Poskentren ini digunakan untuk tempat bagi santri dan santriwati mendapatkan pelayanan kesehatan, termasuk siswi yang sakit atau menagalami gejala PMS dan juga menyediakan obat untuk mengatasi keluhan PMS.

b. Hasil Penelitian

1) Umur

Tabel 1 Distribusi frekuensi berdasarkan umur pada kelas XII yang mengalami PMS di Pondok Pesantren di Sukoharjo

\begin{tabular}{ccc}
\hline $\begin{array}{c}\text { Umur } \\
\text { (tahun) }\end{array}$ & Jumlah & $\begin{array}{c}\text { Prosentase } \\
(\%)\end{array}$ \\
\hline 17 & 24 & 70,6 \\
18 & 7 & 20,6 \\
19 & 3 & 8,8 \\
\hline Total & 34 & 100 \\
\hline \multicolumn{2}{c}{ Sumber : Data Primer 2020 }
\end{tabular}

Karakteristik responden ini berdasarkan umur, bahwa sebagian besar responden berusia 17 tahun sebanyak 24 siswi $(70,6 \%)$, penelitian mengambil responden di Pondok Pesantren Sukoharjo yang sebagian besar tergolong remaja yaitu usia 10-19 tahun. Berdasarkan pengelompokan usia menurut WHO bahwa usia 10-19 tahun termasuk dalam kategori remaja (Siddharam et $a l, 2011)$. Usia remaja ini adalah kelompok usia yang cukup rentan mengalami gangguan menstruasi (Sianipar et al, 2009). Delara et al (2013) yang menyatakan bahwa usia remaja berhubungan signifikan terhadap skor keluhan PMS.

2) Usia menarche 
Tabel 2 Distribusi frekuensi berdasarkan usia menarche pada kelas XII yang mengalami PMS di Pondok Pesantren Sukoharjo

\begin{tabular}{ccc}
\hline $\begin{array}{c}\text { Usia menarche } \\
\text { (tahun) }\end{array}$ & Frekuensi & $\begin{array}{c}\text { Prosentase } \\
(\%)\end{array}$ \\
\hline $10-12$ & 16 & 47,1 \\
$13-15$ & 18 & 52,9 \\
Total & 34 & 100 \\
\hline
\end{tabular}

Sumber : Data Primer 2020

Karakteristik responden ini berdasarkan usia menarche, bahwa sebagian besar usia menarche berusia 13-15 tahun sebanyak 18 siswi $(52,9 \%)$ dan pada usia 10-12 tahun sebanyak 16 siswi $(47,1 \%)$ Usia menarche yang ideal adalah umur 13-14 tahun, kejadian PMS pada umumnya terjadi 2-3 tahun setelah menarche karena pada usia tersebut terjadi perkembangan organ-organ reproduksi dan perubahan hormonal (Puspitasari et al, 2014). Berdasarkan penelitian (City, Wahyuni and Izhar, 2018) bahwa tidak ada hubungan antara usia menarche dengan PMS. Hasil penelitian (Amjad et al, 2015) menemukan bahwa usia menarche $<12$ tahun cenderung mengalami PMS.

3) Lama menstruasi

Tabel 3 Distribusi frekuensi berdasarkan lama menstruasi pada kelas XII yang mengalami PMS di Pondok Pesantren Sukoharjo

\begin{tabular}{ccc}
\hline $\begin{array}{c}\text { Lama } \\
\text { menstruasi } \\
\text { (hari) }\end{array}$ & Frekuensi & $\begin{array}{c}\text { Prosentase } \\
(\%)\end{array}$ \\
\hline$\geq 7$ & 26 & 76,5 \\
$<7$ & 8 & 23,5 \\
Total & 34 & 100 \\
\hline
\end{tabular}

Sumber : Data Primer 2020

Karakteristik responden ini berdasarkan lama menstruasi, bahwa sebagian besar lama menstruasi $\geq 7$ hari sebanyak 26 siswi $(76,5 \%)$ dan pada $<7$ hari sebanyak 8 siswi $(23,5 \%)$. Lama menstruasi pada responden penelitian ini termasuk dalam keadaan normal yaitu antara 510 hari. Selain itu, lama menstruasi tidak mempunyai hubungan signifikan dengan kejadian PMS (Fibriastuti, 2012).

4) Siklus menstruasi

Tabel 4 Distribusi frekuensi berdasarkan siklus menstruasi pada kelas XII yang mengalami PMS di Pondok Pesantren Sukoharjo

\begin{tabular}{ccc}
\hline $\begin{array}{c}\text { Siklus } \\
\text { menstruasi } \\
\text { (hari) }\end{array}$ & Frekuensi & $\begin{array}{c}\text { Prosentase } \\
(\%)\end{array}$ \\
\hline 28 & 26 & 76,5 \\
30 & 8 & 23,5 \\
Total & 34 & 100 \\
\hline Sumber $:$ Data Primer 2020
\end{tabular}

Sumber : Data Primer 2020

Karakteristik responden ini berdasarkan siklus menstruasi, bahwa sebagian besar siklus menstruasi 28 hari sebanyak 26 siswi $(76,5 \%)$ dan pada 30 hari sebanyak 8 siswi $(23,5 \%)$. Umumnya siklus menstruasi normal berkisar antara 21-35 hari dan berbeda-beda pada setiap individu (Canning et al, 2010; Kitamura et al, 2012). Hal ini berarti bahwa panjang siklus menstruasi responden dalam penelitian ini adalah normal. Menurut Fibriastuti (2012) siklus menstruasi tidak berhubungan dengan kejadian PMS.

5) Ganti pembalut

Tabel 5 Distribusi frekuensi berdasarkan ganti pembalut pada kelas XII yang mengalami PMS di Pondok Pesantren Sukoharjo

\begin{tabular}{ccc}
\hline $\begin{array}{c}\text { Ganti pembalut } \\
\text { (kali/hari) }\end{array}$ & Frekuensi & $\begin{array}{c}\text { Prosentase } \\
(\%)\end{array}$ \\
\hline$\geq 3$ & 29 & 85,3 \\
$<3$ & 5 & 14,7 \\
Total & 34 & 100 \\
\hline
\end{tabular}

Sumber : Data Primer 2020

Karakteristik responden ini berdasarkan ganti pembalut, bahwa sebagian besar ganti pembalut $\geq 3$ kali perhari sebanyak 29 siswi $(85,3 \%)$ dan 
pada $<3$ kali perhari sebanyak 5 siswi $(14,7 \%)$. Umumnya ganti pembalut normal berkisar 2-4 kali perhari dan berbeda-beda setiap individu. Hal ini berarti ganti pembalut responden dalam penelitian ini adalah normal. Berdasarkan penelitian (Arum $e t$ al, 2017) bahwa ada hubungan signifikan antara penggunaan jenis pembalut saat menstruasi dengan kejadian keputihan. Jenis pembalut herbal lebih efektif dibandingkan dengan jenis pembalut non hernal/biasa, serta jenis pembalut tidak berhubungan dengan kejadian PMS.

6) Indeks Massa Tubuh (IMT)

Tabel 6 Distribusi frekuensi berdasarkan IMT pada kelas XII yang mengalami PMS di Pondok Pesantren Sukoharjo

\begin{tabular}{lcc}
\hline \multicolumn{1}{c}{ IMT } & Frekuensi & $\begin{array}{c}\text { Prosentase } \\
(\%)\end{array}$ \\
\hline BB kurang & 4 & 11.8 \\
BB ideal & 28 & 82,4 \\
BB lebih & 2 & 5,9 \\
Total & 34 & 100 \\
\hline \multicolumn{2}{c}{ Sumber : Data Primer 2020 }
\end{tabular}

Karakteristik responden ini berdasarkan IMT, bahwa sebagian besar IMT dengan BB ideal sebanyak 28 siswi $(82,4 \%)$, BB kurang sebanyak 4 siswi $(11,8 \%)$ dan BB lebih sebanyak 2 siswi (5,9\%). Berdasarkan penelitian (Lee et al, 2006) bahwa terdapat hubungan antara faktor IMT dan skor gejala keluhan PMS, semakin tinggi IMT akan semakin besar skor keluhan PMS. Faktor IMT berhubungan positip dengan gejala fisik dan emosional PMS, termasuk dalam hal ini edema ekstremitas, nyeri punggung, kram perut, diare, konstipasi, emosi tidak stabil dan mengidam makanan tertentu.

7) Asupan makanan

Responden pada penelitian ini merupakan siswi SMA di
Pondok Pesantren Sukoharjo, sehingga semua responden memiliki asupan makanan yang sama karena responden tinggal di asrama. Berdasarkan penelitian (Amalia, 2013) bahwa konsumsi protein berhubungan nyata negatif terhadap tingkat keluhan PMS, tetapi tidak berhubungan dengan konsumsi energi. Selain itu, konsumsi lemak juga berhubungan negatif dengan tingkat keluhan PMS, dimana semakin tinggi konsumsi lemak, maka tingkat keluhan PMS semakin berkurang (Amalia, 2013). Komposisi lemak tubuh yang rendah dapat mengakibatkan rendahnya kadar estrogen dalam sistem reproduksi sehingga dapat mempengaruhi ketidakseimbangan hormon reproduksi yang dapat menimbulkan PMS dan gangguan menstruasi (Waryana 2010). Rendahnya tingkat kecukupan protein berkontribusi terhadap peningkatan keluhan PMS (Fibriastuti, 2012). Menurut Amalia (2013) menyatakan bahwa konsumsi zat besi tidak berhubungan nyata dengan jenis dan tingkat keluhan PMS. Namun, Linder (1992) dan Facchinetti et al (1991) menyatakan bahwa rendahnya asupan kalsium dan magnesium berperan dalam kontraksi otot, stress dan kecemasan serta sekresi estrogen.

8) Aktivitas sehari-hari

Semua responden dalam penelitian ini memiliki jadwal aktivitas yang sama yaitu terdapat jadwal kegiatan harian siswi dan jadwal mingguan siswi. Hal ini dikarenakan responden tinggal di asrama dan semua aktivitas responden telah diatur dan sesuai jadwal ketentuan dari asrama Pondok Pesantren di Sukoharjo. 
Aktivitas fisik menurut WHO (2017) adalah gerakan tubuh yang dihasilkan oleh otot rangka yang memerlukan pengeluaran energi. WHO/FAO/UNU (2001), aktivitas fisik ringan adalah apabila responden tidak banyak melakukan kegiatan fisik, tidak banyak berjalan kaki dengan jarak yang jauh, menggunakan alat transportasi, tidak melakukan olahraga secara teratur dan lebih banyak menghabiskan waktunya untuk kegiatan dalam posisi berdiri atau duduk, dengan sedikit pergerakan tubuh seperti berbicara, membaca, menonto televisi, mendengarkan radio dan menggunakan komputer. Penelitian Teixeira et al (2013) menunjukkan hubungan negatif antara aktivitas fisik dengan kejadian PMS pada responden yang menderita PMS dengan tingkat aktivitas ringan dan responden sehat dengan aktivitas fisik berat. Dari hasil penelitian tersebut menunjukkan semakin rendah aktivitas fisik semakin tinggi tingkat keluhan PMS, dan semakin tinggi aktivitas fisik maka semakin rendah tingkat keluhan PMS.

\section{KESIMPULAN}

Berdasarkan hasil penelitian di Pondok Pesantren Sukoharjo dengan responden sebanyak 34 siswi kelas XII dengan PMS, didapatkan hasil yaitu mayoritas umur responden yaitu 17 tahun, usia menarche 13-15 tahun, lama menstruasi $\geq 7$ hari, siklus menstruasi 28 hari, ganti pembalut $\geq$ 3 kali perhari dan IMT dengan berat badan ideal.

\section{SARAN}

a. Bagi Responden : siswi harus lebih menjaga kesehatan terutama untuk masalah menstruasi agar masalah sebelum menstruasi tidak menganggu aktivitas dalam belajar, bisa mengontrol emosi agar tidak terlalu cemas menjelang menstruasi, aktivitas lainnya dan menjaga pola makan serta melakukan olahraga yang teratur.

b. Bagi Pondok Pesantren Sukoharjo: perlu mendapatkan perhatian dari pihak sekolah, salah satu upaya untuk mencegah terjadinya PMS yaitu dengan cara memberikan pelajaran tentang pendidikan kesehatan reproduksi khususnya masalah menstruasi.

c. Bagi Profesi Bidan : Bidan diharapkan lebih memperhatikan kesehatan remaja khususnya tentang kesehatan reproduksi seperti mengadakan penyuluhan tentang PMS agar remaja bisa mencegah dan menangani kejadian PMS.

\section{UCAPAN TERIMA KASIH}

Ucapan syukur pada Alloh SWT yang telah memberi ridhoNya dalam menyelesaikan penelitian. Terima kasih penulis sampaikan kepada Kepala Pondok Pesantren Sukoharjo yang telah memberi ijin untuk melakukan penelitian. Terima kasih pula kepada orang tua, suami, anak dan teman-teman atas dukungan dan inspirasinya, serta semua pihak yang telah membantu dalam penelitian ini..

\section{REFERENSI}

ACOG. 2015. Menstruation in Girls and Adolescents: Using The Menstrual Cycle as a Vital Sign. The American College of Obstetricians and Gynecologists.Available: http://www.acog.org/Imedia/CommitteeOpinions/CommitteeonAdolescent HealthCare/co651.pdf?dmc $=1 \&$ ts $=$ 20124T1701404887, diakses tanggal 3 Juni 2019.(1)

Amalia NR. 2013. Hubungan Indeks Massa Tubuh dan Persen Lemak Tubuh dengan Sindrom Pramenstruasi pada Remaja Putri di SMA Bina Insani Bogor. Bogor: Institut Pertanian Bogor. 
Amjad, A., Kumar, R. and Mazher, S. B. 2015. 'Socio-demographic Factors and Premenstrual Syndrome among Women attending a Teaching Hospital in Islamabad, Pakistan'. J. Pionneer Med Sci, 4(4).

Arum Wijayanti, Ika Sumiyarsi, Angesti Nugraheni. 2017. 'Hubungan antara penggunaan jenis pembalut saat menstruasi dengan kejadian keputihan di SMK Negeri 1 Sukoharjo 1'. Jurnal EDUMidwifery Vol 1 No 2.

Basir A.A, Bahrun U., Idris I., 2011. Peran High Sensitivity C-Reactive Protein (hs-CRP) sebagai penanda inflamasi, indeks massa tubuh dan lingkar pinggang terhadap derajad Premenstrual Syndrome pada wanita usia subur. https//pasca.unhas.ac.id/jurnal/files/ pdf

Canning S, Waterman M, Orsi N, Ayres J, Simpson N, Dye L. 2010. The efficacy of hypericum perforatum (St John's Wort) for the treatment of premenstrual syndrome. CNS Drugs. 24(3):207-225.doi:11727047/10/0003-0207/S49.95/0.

Christiany I, Hakimi M, Sudargo T. 2009. Status gizi asupan zat gizi mikro (kalsium, magnesium) hubungannya dengan sindroma premenstruasi pada remaja putri SMU Sejahtera di Surabaya. Jurnal Gizi Klinik Indonesia. 6 (1): 29-34.

City, S. J., Wahyuni, S. D., \& Izhar, M. D. (2018). Determinan Yang Berhubungan Dengan Premenstrual Syndrome ( PMS) pada remaja putri di SMPN 7 Kota Jambi Determinants which correlate with Premenstrual Syndrome ( PMS ) for Adolescent Girls in, 2(1), 5970.

Delara, M., Borzuei, H. and Montazeri, A. (2013) 'Premenstrual Disorders : Prevalence and Associated Factors in a Sample of Iranian Adolescents', 15(8), pp. 695-700. doi: 10.5812/ircmj.2084.
Devi, M. (2009) 'Suplementasi Kapsul Serbuk Daun Torbangun (Coleus Amboinicus Lour) Untuk Menanggulangi Keluhan Sindrom Pramenstruasi Pada Remaja Putri.'

Essel, E. 2009. Premenstrual Syndrome Is Real?. http://www/gsv/edu/. Diakses 3 Juni 2019

Facchinetti F, Borella P, Sances G, Fioroni L, Nappi RE, Genazzani AR. 1991. Oral magnesium successfully relieves premenstrual mood changes. Obstet Gynecol. Aug;78(2):177-81. PMID: 2067759.

Fibriastuti YR. 2012. Analisis faktor yang mempengaruhi sindrom pramenstruasi pada polisi wanita (polwan) di polisi resor kota Cimahi. Bogor: Institut Pertanian Bogor.

Halbreich U. 2009. The etiology, biology and evolving pathology of premenstrual syndromes: clinical procedures and reseach perspectives. Psychoneuro.

Kitamura, M., Takeda, T. and Koga, S. 2012. 'Relationship between premenstrual symptoms and dysmenorrhea in Japanese high school students', pp. 131-133. doi: 10.1007/s00737-012-0266-2.

Lee LK, Chen PC, Lee KK, Kaur J. 2006. 'Menstruation among adolescent girls in Malaysia: a cross-sectional school survey'. Singapore Med J. 47(10), pp. 869874.

Linder M. 1992. Biokimia nutrisi dan metabolisme. Jakarta: penerbit Universitas Indonesia

Mohammadirizi S., Kordi M.. 2013. Association between menstruation signs and anxiety, depression and stress in school girls in Mashhad in 2011-2012. Iranian Journal of Nursing and Midwifery Research. http://www.ncbi.nlm.nih.gov/pmc/a rticles/PMC 3877464/?2013

Nurmiaty, Siswanto AW, Toto Sudargo. 2011. Perilaku Makan dengan Kejadian Sindrom Premenstruasi pada Remaja. Yogyakarta: FK 
UGM.

Oberman, M. 2018. 'Motherhood, Abortion, and the Medicalization of Poverty'. The Journal of law, medicine \& ethics : a journal of the American Society of Law, Medicine \& Ethics, 46(3), pp.665671. doi: $10.1177 / 1073110518804221$

Potter J, Bouyer J, Trussel J, Moreau C. 2009. Premenstrual Syndrome prevalance and fluctuation over time: results from a french population based survey. J Women Health (larchmt). 18 (1): 31-39.

Puspitorini, M.D., Mohammad Hakimi, Ova Emilia. 2007. Obesitas Sebagai Faktor Resiko Terjadinya Premenstrual Syndrome pada Mahasiswa Akademi Kebidanan Pemerintah Kabupaten Kudus. Berita Kedokteran Masyarakat

Saryono dan Waluyo. 2009. Sindrom Premenstruasi. Yogyakarta: Nuha Medika.

Siantina, R. 2010. Hubungan antara Asupan Zat Gizi dan Aktivitas Olahraga dengan Kejadian Premenstrual Syndrome (PMS) pada Remaja Putri di SMAN 1 Padang Tahun 2010. Skripsi, Universitas Andalas.

Sianipar O, Bunawan CN, Almazini P, Calista N, Wulandari P, Rovenska N, Dinanda E, Raisa, Irene, Seno A, Suarthana E. 2009. Prevalensi gangguan menstruasi dan faktorfaktor yang berhubungan pada siswi SMU di kecamatan Pulo Gadung Jakarta Timur. Maj kedokt Indon. 7(59).

Siddharam, S. M., Venketesh, G. M. and Thejeshwari, H. L. 2011. 'A Study of Anemia Among Adolescent Girls in Rural Area of Hassan district, Karnataka, South India .', 2(4), pp. 922-924

Smeltzer SC, Bare BG. 2013. Buku Ajar Keperawatan Medikal Bedah Brunner \& Suddarth. Edisi ke-12. Jakarta : EGC.

Suparman, Edy. 2013. Premenstrual Syndrome. Jakarta : EGC.
Sylvia D., 2010. Sindrom PraMenstruasi. Jakarta : Balai Penerbit FKUI

Teixeira AL, Oliveira EC, Dias MR. 2013. Relationship between the level of physical activity and premenstrual syndrome incidence. Rev Bras Ginecol Obstet. 35(5):210-4

Waryana. 2010. Gizi reproduksi. Yogyakarta: Pustaka Rihama.. 